\title{
RELIABILITY OF AIR SEPARATION MODULE COMPONENTS ON THE NITROGEN GENERATION SYSTEM OF BOEING AIRCRAFT
}

\author{
Wahyu Kurniawan \\ Jurusan Teknik Dirgantara-Sekolah Tinggi Teknologi Adisutjipto \\ kurniawanwahyu97@gmail.com
}

\begin{abstract}
Aircraft is a type of transportation that can reach a certain area in a short time compared to other types of transportation. Every aircraft used will experience a decrease in performance along with the use of flight hours, to maintain and restore the aircraft condition to its original condition, maintenance effectiveness is needed. Aircraft maintenance carried out to keep the aircraft systems or components working properly, one of the components that need maintenance is the Air Separation Module. The purpose of this study to determine the reliability, failure rate, type of failure, and effectiveness of maintenance of the Air Separation Module.
\end{abstract}

Keyword: Air Separation Module, Boeing 737-900ER

\section{Latar Belakang}

Salah satu aspek penting dalam dunia penerbangan khususnya dalam bidang perawatan pesawat terbang adalah keandalaan (reliability). Keandalan dalam dunia engineering sering digunakan dalam mengevaluasi kinerja suatu system ataupun untuk mengevaluasi efektivitas perawatan yang dilakukan dengan keandalan pesawat terbang yang meliputi kelaikan, kemampuan operasional, dan kesiapan operasi dengan mengukur kualitas dari perawatan pesawat yang dilakukan. Tingkat keandalan suatu pesawat dapat dipertahankan dengan melaksanakan perawatan sehingga kemampuan pesawat untuk dapat melaksanakan misi atau fungsi pada kondisi tertentu selama waktu yang ditentukan tetap dalam kondisi laik udara tanpa ada suatu kegagalan dalam operasional pesawat terbang [1]. Setiap pesawat yang digunakan akan mengalami penurunan performance seiring dengan penggunaan jam terbang, sehingga untuk mempertahankan dan mengembalikan kondisi pesawat seperti semula diperlukan efektivitas perawatan. Perawatan pesawat dilakukan untuk menjaga sistem atau komponenkomponen pesawat tetap bekerja dengan fungsi yang baik, salah satu sistem adalah Nitrogen Generation System. Nitrogen Generation System adalah suatu system inert yang dipasang di pesawat terbang yang berfungsi untuk mencegah terjadinya kebakaran dan ledakan dalam tangki bahan bakar pesawat dengan cara mengalirkan nitrogen ke dalam tangki bahan bakar dan meminimalisis oksigen dalam tangki bahan bakar [2][3]. Banyaknya kejadian kebakaran pesawat akibat meledaknya tangki bahan bakar pesawat mengharuskan pesawat mempunyai system inert yaitu dengan cara memasang Nitrogen Generation Sytem (NGS) di dalam pesawat.Berdasarkan informasi yang didapat dari bagian engineering serta alumni yang bekerja di maskapai Lion Air bahwa akhir-akhir ini yang sedang menjadi highlight (permasalahan yang sering muncul) di Nitrogen Generation System yaitu komponen Air Separation Module, dimana permasalahan tersebut dapat mempengaruhi tingkat kemanan pesawat saat sedang beroperasi karena komponen tersebut merupakah salah satu komponen yang penting dalam meminimalisasi terbentuknya segitiga api yang dapat menghasilkan ledakan [4][5][6]. Fidanoglu, M. 2017. “Application of Weibull Distribution Method for Aircraft Component Life Estimation in Civil Aviation Sector"[ 8]. Tingkat keandalan komponen Power Distribution Unit dengan $\mathrm{P} / \mathrm{N}$ 0006648-801 yaitu sebesar 85\%, dan dari perhitungan mengindikasikan jenis kegagalan disebabkan oleh random failure (kegagalan acak).Adolfo Lerry Raimundo M. 2018. "Analisis Keandalan Komponen Air Conditioning System pada pesawat Boeing 737-900ER 
Menggunakan Metode Distribusi Weibull" [7]. Tingkat keandalan pada komponen pack valve dan komponen digital controller mengalami penurunan seiring bertambahnya jam pemakaian. Keandalan komponen pack valve pada 100 hours adalah 91\%, pada 2000 hours adalah 48\%. Sedangkan komponen digital controller, keandalan pada 100 hours adalah $99 \%$ dan pada 2000 hours adalah 87\%.Indo Herbet Hutasoit. 2014. "Analisis Keandalan Komponen Filter pada Nitrogen Generation System Pesawat Boeing 737-900ER Menggunakan Metode Wiebull”[10]. Tingkat keandalan pada komponen filter P/N2040025-104 tingkat keandalannya sebesar 41\%, filter P/N2040025-105 tingkat keandalannya 42\%, dan komponen filter differential pressure switch P/N2040061-102 memiliki nilai keandalan sebesar 50\%. Adapun dari hasil perhitungan mengindekasikan jenis kegagalan pada filter adalah wear out (aus) dengan tipe degradasi gradual dimana laju kegagalan meningkat. Adapun efektivitas perawatan yang dilakukan pada komponen filter yaitu preventive maintenance.Kevin Esa Ferraro. 2019. "Analisis Keandalan Landing Gear Pada Komponen Nose Wheel Assy Atr 72-500 Menggunakan Distribusi Weibull" oleh Tingkat Keandalan pada komponen nose wheel assy berdasarkan pada time failure yaitu 188.13 hours adalah $96 \%$ lalu pada 465.95 hours adalah $47 \%$ dan rata-rata komponen nose wheel assy akan berfungsi sampai mengalami kegagalan pada usia 585 jam 38 menit sedangkan berdasarkan pada cycle yaitu 13 cycle adalah $97 \%$ lalu pada 191 cycle adalah $47 \%$ dan rata-rata komponen nose wheel assy akan berfungsi sampai mengalami kegagalan pada usia 398 jam 13 menit. . Berdasarkan penafsiran nilai beta $(\beta)$ tipe laju kegagalan komponen nose wheel assy pada pesawat ATR 72-500 adalah meningkat, pada flight Hours yang dimana nilai $\beta=3.513864$ pada nose wheel assy adalah $\beta>1$, yang mengindikasikan terjadinya kegagalan aus (wear out). Keselamatan penerbangan merupakan faktor utama dalam mengoperasikan pesawat terbang, dengan cara melakukan perawatan pesawat terbang yang dimulai dari persiapan, pelaksanaan dan proses sertifikasi. Perawatan pesawat terbang dapat didefinisikan seperti semua kegiatan yang dilakukan untuk keandalan (reliability) pesawat terbang, komponen-komponen pesawat udara dan perlengkapannya wajib dalam kondisi laik udara (airworthy) termasuk inspection, repair, service, overhaul dan pergantian parts (CASR Part 43).

\section{Metodologi Penelitian}

Penelitian ini merupakan penelitian yang termasuk dalam penelitian deskriptif yang digunakan untuk menemukan pengetahuan seluas-luasnya terhadap objek penelitian. Penelitian dilakukan di Lion Operation Center maskapai Lion Air yang terletak di Bandara Mas Tangerang. Lion Operation Center merupakan fasilitas yang dimiliki oleh maskapai Lion Air untuk melakukan evaluasi pengerjaan perawatan berupa dokumen-dokumen yang menunjang terciptanya perawatan pesawat yang baik dan mendistribusikan perintah kerja (task card) pelaksanaan perawatan ke line maintenance maupun base maintenance. Pesawat yang menjadi subyek penelitian adalah Boeing 737-900ER yang merupakan salah satu jenis pesawat komersial yang paling banyak dioperasikan di dunia baru-baru ini termasuk Lion Air. Adapun yang menjadi objek penelitian yaitu mengarah pada keandalan komponen Air Separation Module pada Nitrogen Generation System. Langkah-langkah penelitian sebagai berikut:

a. Studi Literatur, yaitu langkah atau tahapan pengumpulan informasi melalui pembelajaran dari kepustakaan dan berbagai sumber lainnya yang berkaitan dengan pembahasan.

b. Pengumpulan Data

Pengumpulan data yaitu mulai dari proses mengumpulkan data-data yang dibutuhkan tujuannya untuk dilakukan analisis, data yang diperlukan yaitu Defect Monitoring Report, IPC, Component Maintenance Manual, AMM. 
c. Pengolahan Data

Melakukan input data yang telah didapatkan dari hasil penelitian dan memastikan kembali bahwa data yang didapatkan telah mencukupi dan dapat digunakan untuk melakukan analisis.

d. Analisis Hasil dan Pembahasan

Melakukan perhitungan menggunakan data yang telah diolah sebelumnya, hasil perhitungan yang didapat selanjutnya dilakukan analisis berdasarkan dasar teori yang ada untuk menentukan jenis tiap parameter yang didapatkan untuk mendapatkan kesimpulan.

e. Kesimpulan dan Saran

Kesimpulan merupakan bagian yang membahas tentang jawaban dari rumusan masalah serta memenuhi harapan. Selain itu kesimpulan juga menjelaskan tentang manfaat dari penelitian ini. Saran merupakan manifestasi untuk dilaksanakan sesuatu yang tidak ada dalam penelitian ini dan layak untuk dilaksanakan, selain itu juga saran dicantumkan karena melihat adanya jalan keluar untuk mengatasi permasalahan atau kelemahan yang ada.

\section{Hasil dan Pembahasan}

Data failure time diambil dari data Defect Monitoring Report, data Defect Monitoring Report adalah data laporan pemantauan kerusakan dimana komponen tersebut terpasang pada pesawat sampai komponen tersebut mengalami kegagalan. Kegagalan yang terjadi pada komponen Air Separation Module pesawat Boeing 737-900ER dalam kurun waktu Oktober 2017 sampai dengan September 2019 didapatkan jumlah kegagalan sebanyak 18 kali mengenai komponen Air Separation Module. Usia komponen diambil dari data time in service, time in service adalah waktu dimana komponen tersebut terpasang pada pesawat sampai komponen tersebut mengalami kegagalan. Usia komponen Air Separation Module.

Dalam menentukan usia komponen dilakukan perhitungan dengan rumus yaitu:

$$
\text { Usia Komponen }=\text { Remove Time }- \text { Install Time }
$$

Tabel 1. Usia Komponen Air Separation Module dalam Flight Hours

\begin{tabular}{|c|c|c|c|}
\hline No & Data Install Time & Data Remove Time & Usia Komponen \\
\hline 1 & 11729 & 12026 & 297 \\
\hline 2 & 13211 & 14308 & 1097 \\
\hline 3 & 14941 & 16810 & 1869 \\
\hline 4 & 4063 & 6439 & 2376 \\
\hline 5 & 0 & 2578 & 2578 \\
\hline 6 & 4478 & 8243 & 3765 \\
\hline 7 & 7898 & 12874 & 4976 \\
\hline 8 & 5640 & 10907 & 5267 \\
\hline 9 & 9132 & 15610 & 6478 \\
\hline 10 & 2448 & 10015 & 7567 \\
\hline 11 & 9770 & 19444 & 9674 \\
\hline 12 & 0 & 10767 & 10767 \\
\hline 13 & 7499 & 18364 & 10865 \\
\hline 14 & 0 & 11764 & 11764 \\
\hline 15 & 551 & 15394 & 14843 \\
\hline
\end{tabular}




\begin{tabular}{|l|c|c|c|}
\hline 16 & 2534 & 21136 & 18602 \\
\hline 17 & 5077 & 24813 & 19736 \\
\hline 18 & 163 & 21299 & 21136 \\
\hline
\end{tabular}

Dalam melakukan perhitungan laju kegagalan yaitu dengan memasukan parameter ( $\boldsymbol{\beta})$ dan

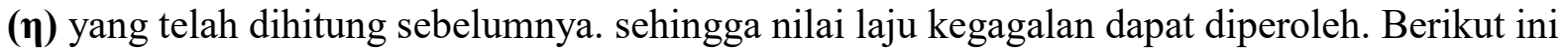
adalah contoh perhitungan nilai laju kegagalan komponen Air Separation Module untuk (t) = 200. Tabel dan grafik laju kegagalan komponen Air Separation Module

$$
\lambda(t)=\frac{F(t)}{R(t)}=0.000214
$$

Tabel 2. Perhitungan Laju Kegagalan Komponen Air Separation Module dalam Cycle

\begin{tabular}{|c|c|c|c|c|c|}
\hline Time & $\lambda(\boldsymbol{t})$ & Time & $\lambda(\boldsymbol{t})$ & Time & $\boldsymbol{\lambda}(\boldsymbol{t})$ \\
\hline 200 & 0.000214 & 1500 & 0.000162 & 10000 & 0.000125 \\
\hline 350 & 0.000198 & 3000 & 0.000147 & 12500 & 0.000121 \\
\hline 500 & 0.000189 & 5000 & 0.000137 & 14500 & 0.000119 \\
\hline 750 & 0.000179 & 7000 & 0.000131 & 15500 & 0.000118 \\
\hline 1000 & 0.000172 & 9000 & 0.000127 & 16500 & 0.000117 \\
\hline
\end{tabular}

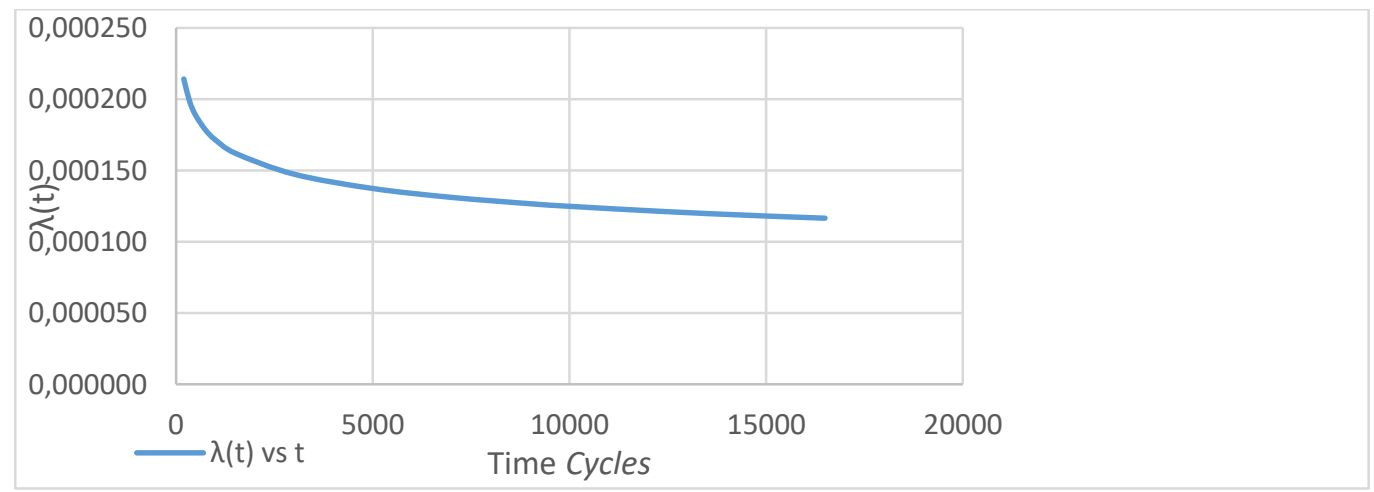

Gambar 1. Grafik Laju Kegagalan Komponen Air Separation Module dalam Cycle

Dari hasil perhitungan yang telah diubah dalam bentuk grafik diatas laju kegagalan semakin menurun (decreasing failure rate) seiring dengan bertambahnya waktu pemakaian komponen. Kondisi ini mirip dengan kurva bathub yang memiliki nilai $\boldsymbol{\beta}<\mathbf{1}$. Dimana apabila dilihat dari hasil perhitungan shape parameter komponen Air Separation Module diperoleh nilai $(\boldsymbol{\beta})=\mathbf{0 . 8 6 1 9 6 3}$, sehingga hal tersebut dikategorikan sebagai kegagalan dini (infant mortality). Kegagalan ini umumnya disebabkan karena adanya kesalahan pada manufacturing. missassembly. quality control yang kurang baik dan permasalahan pada saat overhaul. Pada dasarnya sebuah komponen tidak diharapkan mengalami kegagalan dini. karena sebagian besar komponen pastinya didesain agar terhindar dari kegagalan sampai komponen tersebut mendekati batas umurnya.Perhitungan rata-rata waktu komponen mengalami kegagalan (mean time to failure) yaitu dengan menggunakan persamaan (2.5). Dari distribusi Weibull didapatkan nilai shape parameter $(\beta)=0.946803$ dan scale parameter $(\eta)=9665.02$. Dari nilai tersebut dapat dihitung sebagai berikut: 
$M T T F=\eta \cdot \Gamma\left(1+\frac{1}{\beta}\right)$

Nilai $\Gamma(\mathrm{x})$ ditentukan dengan menghitung nilai $\mathrm{x}$ terlebih dahulu

$x=\left(1+\frac{1}{\beta}\right)=\left(1+\frac{1}{0.946803}\right)=2.056186$

Didapatkan nilai $\mathrm{x}=2.056186$, sehingga didapatkan nilai $\Gamma(\mathrm{x})=1.02218$ dengan melihat pada tabel Gamma yang terdapat pada lampiran. Nilai MTTF komponen Air Separation Module yaitu sebagai berikut:

$$
\begin{aligned}
\text { MTTF } & =\eta \cdot \Gamma\left(1+\frac{1}{\beta}\right) \\
& =9665.02 \times 1.02218\left(1+\frac{1}{0.946803}\right) \\
& =20313.9 \text { hours }
\end{aligned}
$$

Dari hasil perhitungan mean time to failure komponen Air Separation Module diperoleh hasil MTTF = 20313.9 hours, menunjukkan bahwa rata-rata komponen Air Separation Module akan berfungsi sampai mengalami kegagalan saat mencapai waktu 20313 jam dan 54 menit. Nilai MTTF ini sudah sesuai dengan teori yang ada, yaitu ketika $\beta<1$ maka nilai MTTF harus lebih besar daripada nilai $\eta$.Untuk dapat mengetahui karakteristik jenis kegagalan (failure) pada komponen Air Separation Module diperlukan parameter yang menunjukkan karakteristik jenis kegagalan yang terjadi. Parameter yang digunakan untuk mengetahui karakteristik jenis kegagalan pada komponen Air Separation Module adalah parameter beta $(\beta)$. Setelah didapatkan nilai $(\beta)$ maka dapat ditentukan karakteristik jenis kegagalannya. Berdasarkan data yang ada kegagalan pada komponen Air Separation Module paling sering di sebabkan oleh kegagalan pada filter (filter blocked), dan hasil perhitungan yang diperoleh nilai $\beta$ pada komponen Air Separation Module yaitu $\beta=0.946803$ untuk usia komponen dalam hours dan $\beta=0.861963$ untuk usia komponen dalam cycle. Komponen Air Separation Module memiliki $\beta<1$ yang artinya komponen tersebut memiliki karakteristik jenis kegagalan dini (implies infant mortality) yaitu jenis kegagalan yang terjadi pada saat usia komponen masih di awal penggunaan (early age). Grafik laju kegagalan (failure rate) menunjukkan penurunan laju kegagalan seiring dengan waktu penggunaan komponen dan laju kegagalan tertinggi terletak pada awal penggunaan komponen, hal ini sesuai dengan kurva bathub yang mengklasifikasikan jenis kegagalan komponen Air Separation Module sebagai kegagalan dini (implies infant mortality). Jenis kegagalan early failure ini semakin diperkuat dengan diperoleh nilai MTTF sebesar 20313 jam dan 54 menit, sedangkan waktu rata-rata komponen air separation module melakukan pergantian tidak terjadwal atau mean time between unscheduled removal (MTBUR) yaitu pada usia 55000 hours (lihat pada lampiran 4). Dengan perbandingan nilai MTTF yang rendah dari total nilai MTBUR maka jenis kegagalan pada komponen Air Separation Module semakin kuat menunjukkan pada jenis kegagalan dini (early failure). Berdasarkan teori yang ada, jenis kegagalan dini (early failure) diperkirakan terjadi karena adanya permasalahan pada saat proses manufacture komponen, terjadinya kesalahan pada waktu pemasangan (missassambly), dan pengawasan yang kurang baik pada kualitas komponen (quality control).Untuk dapat mengetahui analisis efektivitas perawatan pada komponen Air Separation Module diperlukan sebuah parameter yang menunjukkan jenis kegagalan yang terjadi pada komponen Air Separation Module dengan P/N 2030157-102. Dari hasil perhitungan dengan menggunakan distribusi Weibull didapatkan nilai $\beta=0.946803$ untuk perhitungan dalam hours, sedangkan dalam perhitungan cycle didapatkan nilai $\beta=0.861963$, mengindikasikan terjadinya kegagalan dini sesuai dengan ketetapan yang berlaku yaitu $\beta<1$. Adapun jenis perawatan yang diperlukan untuk jenis kegagalan dini adalah preventive maintenance. Perawatan preventive merupakan suatu tindakan pencegahan terjadinya kerusakan pada komponen yang masih berfungsi dengan baik dengan tujuan untuk meningkatkan kemampuan komponen tersebut. 
Berdasarkan data yang ada kegagalan pada komponen Air Separation Module paling sering di sebabkan oleh kegagalan pada filter (filter blocked), kegagalan yang terjadi pada filter ini biasanya disebabkan oleh kualitas udara yang masuk ke dalam filter kurang baik sehingga menyebabkan filter tersumbat oleh partikel-partikel udara yang kurang baik seperti debu dan lain-lain. Tindakan preventive yang dapat dilakukan pada filter Air Separation Module yaitu dengan melakukan periodic inspection untuk mengetahui kondisi terkini dari komponen tersebut, melakukan cleaning, proses assembly yang baik, melakukan pergantian komponen sebelum masa komponen habis. Untuk kegagalan air separation module yang paling sering disebabkan oleh filter maka di rekomendasikan untuk melakukan cleaning secara berkala pada filter untuk menghindari terjadinya penyumbatan yang dapat mengakibatkan kegagalan pada filter tersebut. Sehingga dengan beberapa tindakan preventive yang dilakukan diharapkan dapat meningkatkan performa komponen menjadi lebih baik dan usia pemakaian menjadi lebih lama.

\section{Kesimpulan}

Tingkat keandalan pada komponen Air Separation Module dengan P/N 2030157-102 pada usia komponen 250 hours yaitu 0.969071, sedangkan saat usia 200 cycles yaitu 0.951506 dan mengalami penurunan performance seiring dengan bertambahnya usia komponen yang disebabkan oleh meningkatnya jam terbang (flight hours) dan cycle (flight cycles). Tingkat laju kegagalan komponen Air Separation Module dengan P/N 2030157-102 yaitu menurun dan laju kegagalan tertinggi terletak pada awal penggunaan komponen. Pada flight hours diperoleh nilai $\beta=0.946803(\beta<1)$ yang mengindikasikan terjadinya kegagalan dini (early failure atau infant mortality). Pada flight cycles diperoleh nilai $\beta=0.861963(\beta<1)$ yang mengindikasikan terjadinya kegagalan dini (early failure atau infant mortality). Rata-rata usia komponen Air Separation Module akan berfungsi sampai mengalami kegagalan pada usia 20313 jam 54 menit, dan untuk nilai Mean Time Between Unschedule Removal (MTBUR) sebesar 55000 hours yang merupakan usia komponen yang telah ditetapkan oleh pihak manufaktur. Dengan perbandingan nilai MTTF yang rendah dari total nilai MTBUR maka jenis kegagalan pada komponen Air Separation Module semakin kuat menunjukkan pada jenis kegagalan dini (early failure).Efektivitas perawatan yang diperlukan pada komponen Air Separation Module dengan $\mathrm{P} / \mathrm{N}$ 2030157-102 adalah dengan melakukan jenis tindakan perawatan preventive yang merupakan suatu tindakan pencegahan timbulnya kerusakan pada komponen yang masih berfungsi dengan baik. Tindakan preventive yang dapat dilakukan untuk mencegah terjadinya kegagalan pada filter Air Separation yaitu dengan melakukan periodic inspection untuk mengetahui kondisi terkini dari komponen tersebut, melakukan cleaning, proses assembly yang baik, melakukan pergantian komponen sebelum masa komponen habis. Sehingga dengan beberapa tindakan preventive yang dilakukan dapat meningkatkan performa komponen menjadi lebih baik dan usia pemakaian menjadi lebih lama.

\section{Daftar Pustaka}

[1] Arbenety, Robert B. 1993. "The New Weibull Handbook”, 536 Oyster Road North Palm Beach, Florida.

[2] Blanchard, B.S,D. Verma, E.L. Peterson. 1994 “Maintainability”. John Wiley \& Sons Ins., New York.

[3] Boeing, A., 2021. 737-900 and 737-900ER SSW | Aviation Partners Boeing. [online] Aviationpartnersboeing.com. http://www.aviationpartnersboeing.com/products_737_900_900ER.php. [Accessed 27 January 2021].

[4] Civil Aviation Safety Regulation Part 43 Revision 1 Maintenance, Preventive Maintenance, Rebuilding, and Alteration. 
[5] Component Maintenance Manual, Air Separation Module, ATA Chapter 47, 737600/700/800/900.

[6] Ebeling, Charles E. 1997. "An Introduction to Reliability and Maintainability Engineering”, St. Louis San Francisco, California.

[7] Ferraro, Kevin Esa. 2019. “Analisis Keandalan Landing Gear Pada Komponen Nose Wheel Assy ATR 72-500 Menggunakan Distribusi Weibull. Sekolah Tinggi Teknologi Adisutjipto. Yogyakarta.

[8] Fidanoglu, M., Ungor, U., Ozkol, I., \& Komurgoz, G. (2017). “Application of Weibull Distribution Method for Aircraft Component Life Estimation in Civil Aviation Sector". Journal of Traffic and Logistics Engineering Vol, 5(1).

[9] Hutasoit, Indo Herbet. 2014. "Analisis Keandalan Komponen Filter Pada Nitrogen Generation System Pesawat Boeing 737-900ER Menggunakan Metode Weibull”. Sekolah Tinggi Teknologi Adisutjipto. Yogyakarta. 